\title{
Factors Controlling Shale Reservoirs and Development Potential Evaluation: A Case Study
}

\author{
Chao Luo $\mathbb{D}^{1,2,3}$ Hun Lin $\left(\mathbb{D},{ }^{1}\right.$ Yujiao Peng $\left(\mathbb{D},{ }^{1}\right.$ Hai Qu $\left(\mathbb{D},{ }^{1}\right.$ Xiaojie Huang $\left(\mathbb{D},{ }^{1}\right.$ Nanxin Yin $(\mathbb{D})$, \\ Wei Liu iD, 4 and Xuanbo Gao iD ${ }^{1}$ \\ ${ }^{1}$ Chongqing University of Science \& Technology, Chongqing 401331, China \\ ${ }^{2}$ Engineering Research Center of Development and Management for Low to Ultra-Low Permeability Oil \& Gas Reservoirs in \\ West China, Ministry of Education, Xi'an Shiyou University, Xi'an, Shanxi 710065, China \\ ${ }^{3}$ State Key Laboratory of Shale Oil and Gas Enrichment Mechanisms and Effective Development, Beijing 100083, China \\ ${ }^{4}$ Chongqing University, Chongqing 400044, China
}

Correspondence should be addressed to Hun Lin; linhun016@aliyun.com

Received 31 December 2020; Revised 3 February 2021; Accepted 6 February 2021; Published 24 February 2021

Academic Editor: Zhiming Chen

Copyright $\odot 2021$ Chao Luo et al. This is an open access article distributed under the Creative Commons Attribution License, which permits unrestricted use, distribution, and reproduction in any medium, provided the original work is properly cited.

\begin{abstract}
The shale of the Lower Silurian Longmaxi Formation is an important gas-producing layer for shale gas development in southern China. This set of shale reservoir characteristics and shale gas development potential provide an important foundation for shale gas development. This study takes wellblock XN111 in the Sichuan Basin, China, as an example and uses X-ray diffraction (XRD), scanning electron microscopy (SEM), isothermal adsorption, and other techniques to analyze the shale reservoir characteristics of the Lower Silurian Longmaxi Formation. The results show that the Lower Silurian Longmaxi Formation was deposited in a deep-water shelf environment. During this period, carbonaceous shale and siliceous shale characterized by a high brittle mineral content (quartz $>40 \mathrm{wt} . \%$, carbonate mineral $>10 \mathrm{wt} . \%)$ and a low clay mineral content $(<30 \mathrm{wt} . \%$, mainly illite) were widely deposited throughout the region. The total organic carbon (TOC) content reaches up to 6.07 wt.\%, with an average of $2.66 \mathrm{wt} . \%$. The vitrinite reflectance is $1.6-2.28 \%$, with an average of $2.05 \%$. The methane adsorption capacity is $0.84-$ $4.69 \mathrm{~m}^{3} / \mathrm{t}$, with an average of $2.92 \mathrm{~m}^{3} / \mathrm{t}$. Pores and fractures are developed in the shale reservoirs. The main reservoir space is composed of connected mesopores with an average porosity of $4.78 \%$. The characteristics and development potential of the shale reservoirs in the Lower Silurian Longmaxi Formation are controlled by the following factors: (1) the widespread deepwater shelf deposition in wellblock XN111 was a favorable environment for the development of high-quality shale reservoirs with a cumulative thickness of up to $50 \mathrm{~m}$; (2) the high TOC content enabled the shale reservoir to have a high free gas content and a high adsorptive gas storage capacity; and (3) the shale's high maturity or over maturity is conducive to the development of pores and fractures in the organic matter, which effectively improves the storage capacity of the shale reservoirs. The reservoir characteristic index was constructed using the high-quality shale's thickness, gas content, TOC, fracture density, and clay content. Using production data from shale gas wells in adjacent blocks, a mathematical relationship was established between the Estimated Ultimate Recovery (EUR) of a single well and the Reservoir Characteristics Index (Rci). The EUR of a single well in wellblock XN111 was estimated.
\end{abstract}

\section{Introduction}

As an important supplement of and replacement for conventional natural gas resources, shale gas has become a hot spot in global natural gas exploration and development [1-3]. Shale gas is a type of unconventional natural gas, which occurs in shale reservoirs that are rich in organic matter
$[4,5]$. Such reservoirs have the characteristics of selfgenerated self-storage, low porosity, and low permeability [6]. Several sets of organic-rich shales were developed in the Paleozoic and Mesozoic in the Upper Yangtze region of southern China [7]. The shale reservoirs of the Lower Cambrian Niutetang Formation and the Lower Silurian Longmaxi Formation are the most well developed $[8,9]$, and their shale 
gas resources have great potential. Among them, the evaluation and exploration of shale gas resources in the Sichuan Basin and its surrounding areas have achieved remarkable results and an excellent understanding [10, 11]. By the end of 2019, the cumulative proven shale gas reserves of the Upper Ordovician Wufeng Formation and the Lower Silurian Longmaxi Formation had exceeded $1.8 \times 10^{8} \mathrm{~m}^{3}$ [12]. The commercial development of shale gas in Fuling, Changning, Weiyuan, Zhaotong, Yongchuan, and other areas indicates that China's shale gas has entered a stage of industrial-scale exploitation [13], which is of farreaching significance to China's unconventional gas development and energy structure optimization. The Longmaxi Formation shale is widely distributed in the Sichuan Basin and its periphery [14], and it is the key strata of marine shale gas exploration and development in China. Shale gas reservoirs are controlled by their sedimentary environments [15], tectonic movement [16], diagenesis, and pressure evolution $[17,18]$. Shale gas reservoirs' characteristics are significantly different under different geological conditions [19], which determine the development characteristics and distribution of the high-quality shale gas reservoirs in the Longmaxi Formation. The characteristics of shale reservoirs [20] and their development potential [21] are the most critical factors limiting shale gas development. Some studies have examined nanopores of shale reservoirs by a field emission scanning microscope-focused ion beam [22-24]; some work have studied on the gas flow behavior of shale gas $[25,26]$; and others have proposed criteria for identifying high-quality shale reservoirs [27, 28]. Some studies have evaluated the potential of shale reservoirs; most of them focus on static resource potential and development potential. For example, Guo et al. (2020) has proposed a method to evaluate the resource potential of shale reservoir, which takes the heterogeneity of shale reservoir into account and could correct the TOC difference [29]. Viet and Hyundon [30] analyze the production potential and economic feasibility in a shale gas reservoir by using an economic indicator. Since shale gas is mainly concentrated in micronanoscale pores $[31,32]$, it is of great significance to explore the factors influencing the development of shale reservoirs and to determine the resource scale that determines the development potential of shale gas in order to clarify the development mechanism of high-quality shale reservoirs and the efficient development mechanism of shale gas.

Taking the wellblock XN111 in the Sichuan Basin as an example, the shale's geochemical and mineralogical characteristics were obtained using X-ray diffraction, scanning electron microscopy, isothermal adsorption, and other techniques. The structure, reservoir space, and reservoir fluid parameters of the shale reservoir in the Longmaxi Formation in well XN111 were identified. The main factors affecting the shale gas accumulation in this area were investigated. The shale gas reserves were estimated using the volume method. In addition, the calculation of the single well shale gas development potential provides theoretical support for shale gas exploration in the Sichuan Basin and in similar basins in the future.

\section{Regional Geologic Setting}

From the Late Sinian, the Upper Yangtze Basin gradually entered a stable thermal subsidence stage, with the Upper Yangtze Platform sandwiched between the South China and Qinling oceans $[33,34]$. In the Late Caledonian, the Upper Yangtze Platform area formed a craton depression basin in the Early-Middle Silurian due to the collision and compression between the Cathaysia Plate and the Yangtze Plate [35] when the South China Ocean was closed. The Late Ordovician-Early Silurian was a period of intense compression in southern China [36]. Under the continuous subduction of the Gutethys Ocean, the scope of the uplifted subcratonic basin where the Sichuan Basin was located was further reduced [37], and in the Early-Middle Ordovician, the sea area with broad sea characteristics was transformed into a sea area restricted by underwater uplift (Figure 1). With the further uplift of the paleo-uplift in the basin, marine shale with a wide distribution [38], a large thickness, and a low deposition rate were formed in an anoxic deep-water shelf environment at medium depths.

The Longmaxi Formation was stable in the Sichuan Basin in the Early Silurian. In the Upper Yangtze region, the Early Silurian Longmaxi Formation inherited the scale of the transgression in the Middle-Late Ordovician [39]. Due to the continuous and stable subsidence of the crust, the transgression scale was large, the environment was stable, and the lithologic combination was relatively stable [40]. It was rich in lithology, radiolarians, and sponge containing bone spicules, which were distributed throughout the basin, representing a group of offshore continental shelf strata deposited under reducing conditions [41]. Well XN111 is located in the southwestern part of the Upper Yangtze Platform, which is on the western margin of the Sichuan Basin. The Longmaxi Formation in well XN111 consists of five types of petrofacies: ordinary shale, siliceous shale, carbonaceous shale, silty shale, and calcareous shale. The lower part of the shale of the Longmaxi Formation in well XN111 is composed of black carbonaceous mudstone, which is rich in graphitization stone, rich in organic matter, and stable in distribution. The upper lithology is mainly gray black, black thin-middle-layered carbonaceous shale, and siltstone with banded and lensed argillaceous micritic limestone.

\section{Database and Methodology}

This study is based on $168 \mathrm{~m}$ of cores, 108 thin sections, $\mathrm{X}$-ray diffraction (XRD) data for 24 samples, source rock data for 29 samples (vitrinite reflectance, total organic carbon (TOC) content, and macerals), and scanning electron microscope (SEM) observations of 47 samples from wellblock XN111.

The XRD analyses were conducted using a BRUKER D8 ADVANCE diffraction tester. The test conditions were as follows: $\mathrm{Cu}$ target, $\mathrm{K}$ radiation, $40 \mathrm{kV}$ tube voltage, and $30 \mathrm{~mA}$ tube current. After the test, a corresponding analysis was carried out using the material standard powder diffraction data. Before the TOC analysis, the samples were dried and ground to 80 mesh. The determination was completed using a CS- 


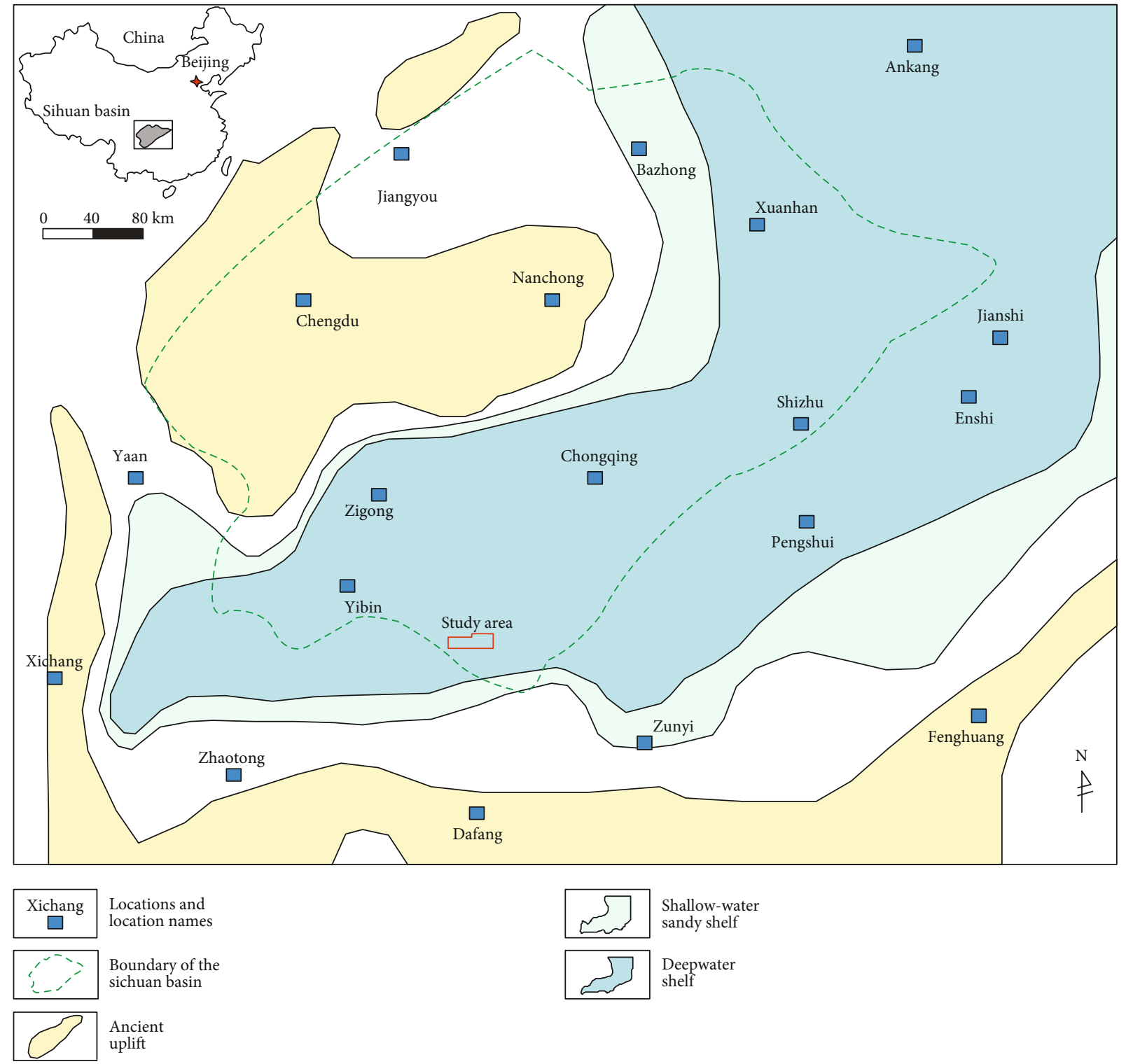

FIgURE 1: Structural sketch map and sedimentary environment of the Sichuan Basin, southern China.

344 analyzer. The vitrinite reflectance (Ro) was determined using a Zeiss MPV-SP photometer. The carbon dioxide/nitrogen isothermal adsorption experiment was performed using an Autosorb IQ3 automatic specific surface and pore size distribution analyzer produced by Kantar. The shale samples were broken into 60-80 samples and dried in an oven at $110^{\circ} \mathrm{C}$ for $12 \mathrm{~h}$. Then, the Autosorb-IQ3 automatic specific surface and pore size distribution analyzer was placed under vacuum conditions at $110^{\circ} \mathrm{C}$ for $12 \mathrm{~h}$ before degassing. After the analyses, the carbon dioxide adsorption data and nitrogen adsorption data were interpreted using the density functional theory (DFT) model to obtain relevant information, such as the pore volume and specific surface area. The macropore volume and specific surface area were obtained by subtracting the micropore and mesopore volumes and the specific surface area from the total pore volume and specific surface area of the nitrogen adsorption data, respectively.
An argon ion polishing-field emission scanning electron microscope (SEM) was used for the observation. The images were obtained using an S-4700 cold field emission scanning electron microscope (SEM), and then, the images were uniformly binarized and parameterized.

\section{Results}

4.1. Mineralogy. The X-ray diffraction analysis of the rock samples revealed that the minerals in the shale include quartz, feldspar, calcite, dolomite, pyrite, and clay (Figure 2), among which the clay minerals are mainly illite, an I/milled layer, and chlorite. The quartz content of the high-quality shale in the Longmaxi Formation is high, accounting for $42.3 \%$ on average. This is followed by calcite and dolomite, with average contents of $13.5 \%$ and $12.9 \%$, respectively, and small amounts of feldspar and pyrite. The clay mineral content is generally low, ranging from $5.1 \%$ to $58.2 \%$, with an average 


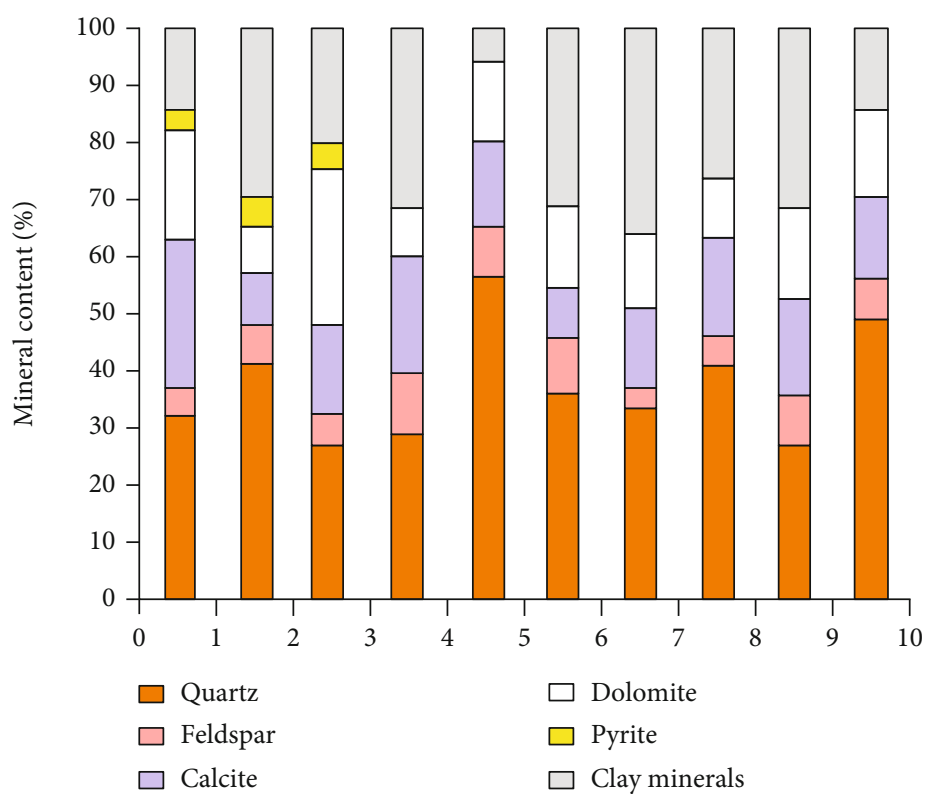

Figure 2: Mineral composition of the shale reservoir in the Longmaxi Formation.

of $23.8 \%$. It is mainly composed of illite and does not contain montmorillonite.

4.2. Fractures. Tectonic fractures, bedding fractures, and diagenetic shrinkage fractures are the most common types of fractures in the Longmaxi Formation shale (Figure 3). The fractures are unevenly distributed. The structural fractures are usually divided into filled and unfilled types. High-angle structural fractures can be seen in the siliceous shale of the lower Longmaxi Formation. Obvious specular and scratches are usually visible on the structural fracture surfaces. The structural fractures in the individual strata are particularly well developed. The image logging data show that there are 27 high-resistance structural fractures in the $2443 \mathrm{~m}$ deep section of the Longmaxi Formation in well XN111, and the strike direction is $70-80^{\circ} \mathrm{NE}$. The size of the structural fractures is usually several millimeters, making them the dominant channel for natural gas migration and seepage.

The foliation is generally horizontal and patchy, and it was observed in both outcrops and the core samples, which is a unique feature of the shale. In the quiet and stable deep-water depositional environment, due to the low deposition rate, the sediments developed laminar accumulation features. However, due to the high organic matter content, under diagenetic compaction, the organic matter and clay minerals contracted strongly and formed bedding joints between the thin bedding. They are basically several microns in size and generally formed in the carbonaceous shale. Diagenetic shrinkage cracks are microcracks formed by dehydration due to the evaporation of water during diagenesis. Mineral particles are often distributed, and some of them can be broken into fragments. The width of the fractures is small and irregular.

In addition to macrofractures that can be resolved using the core samples and the image logging data, a large number of microfractures were also observed in the Longmaxi For- mation. The microfractures generally include filling fractures, dissolution fractures, interlayer fractures between clay minerals, edge fractures between mineral particles, and microfractures from organic hydrocarbon generation. The causes of microcracks are varied. During diagenesis, changes in the mineral facies will cause the formation of microfractures, such as the dehydration of clay minerals. As the depth of the formation increases, the compaction leads to fracture caused by particle fracturing. Interstitial carbonate material is easily dissolved to form dissolution fractures. In the process of hydrocarbon generation, as the hydrocarbon generation increases, when the breakthrough pressure is reached, a large number of microfractures will be formed. Tectonic activity produces stress, resulting in microfractures between flaky clay minerals and clastic particles. Microfractures can also be formed within and between debris particles under the action of external forces.

\subsection{Organic Geochemical Characteristics}

4.3.1. TOC. The TOC content of the Longmaxi shale reaches a maximum of $6.07 \mathrm{wt} . \%$, with an average of $2.66 \mathrm{wt} . \%$ (Figure 4). The TOC content varies with the lithology, and the siliceous shale and clay shale contents are the highest. In the lower part of the Longmaxi shale, the TOC content gradually decreases upward.

4.3.2. Thermal Maturity. The Longmaxi shale is at a highly mature stage [42], and the equivalent vitrinite reflectance is $1.6-2.28 \%$, with an average of $2.05 \%$. The Ro value indicates that the source rock has reached the hot gas window.

4.3.3. Gas Content. The gas-bearing property of the shale is strongly heterogeneous, and the gas-bearing properties of the different strata are significantly different. The methane adsorption capacity of the shale is usually related to the organic carbon content, the degree of thermal evolution, 


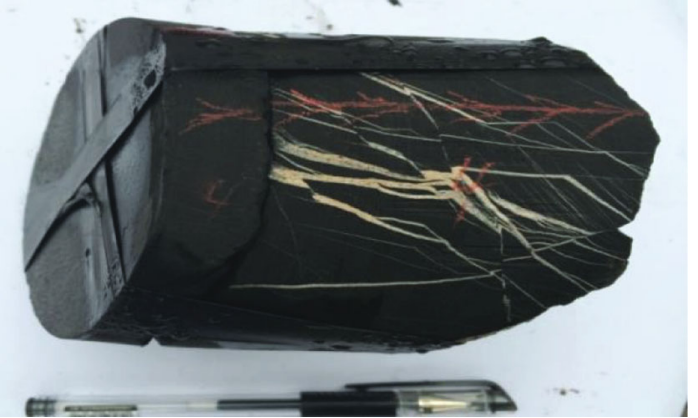

(a)

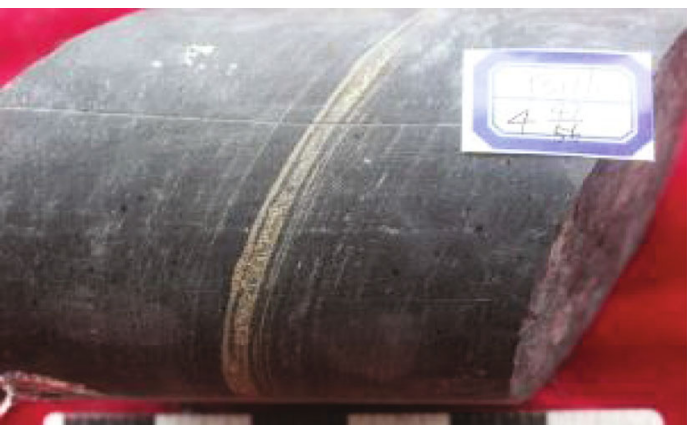

(c)

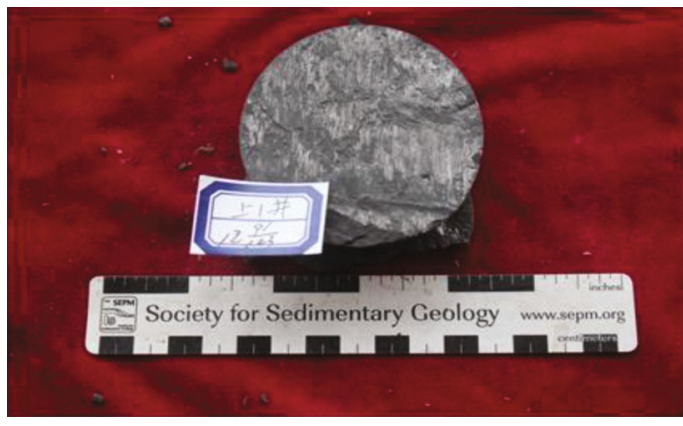

(e)

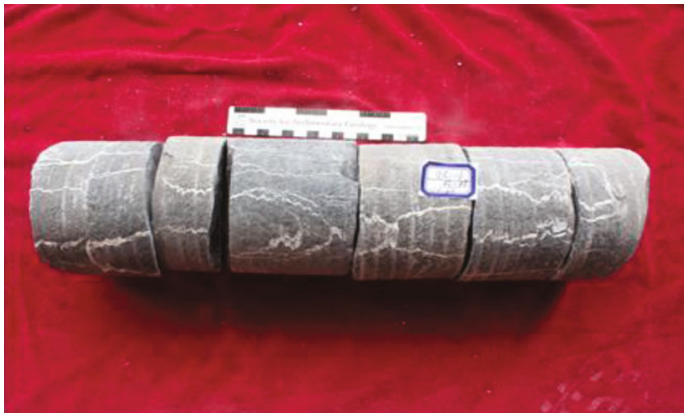

(b)

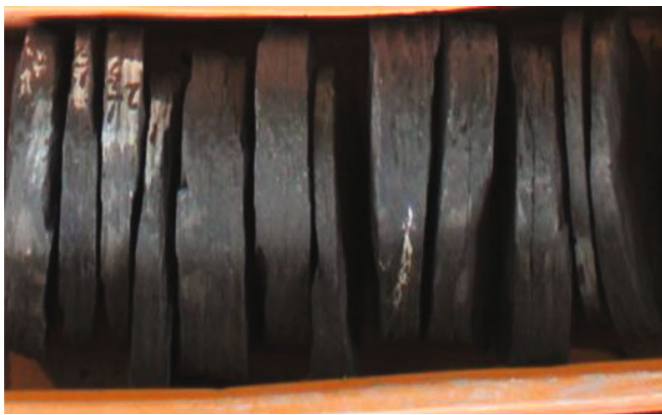

(d)

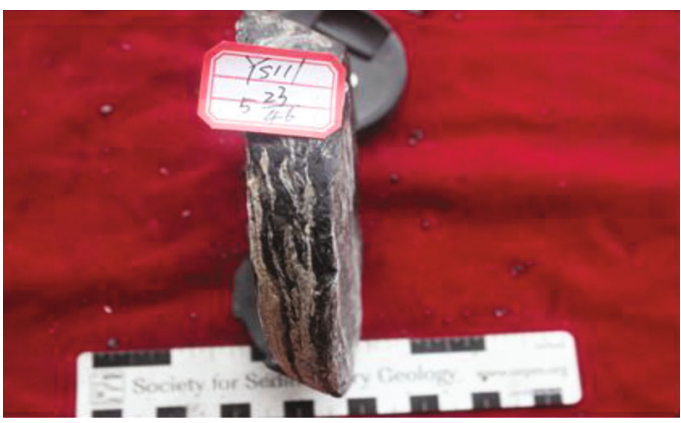

(f)

FIgURE 3: Characteristics of the shale fractures in the Longmaxi Formation. (a) High-angle fractures filled with calcite; (b) high-angle fractures filled with calcite; (c) unfilled high-angle fractures; (d) lamellation; (e) diagenetic shrinkage fractures; and (f) diagenetic shrinkage fractures.

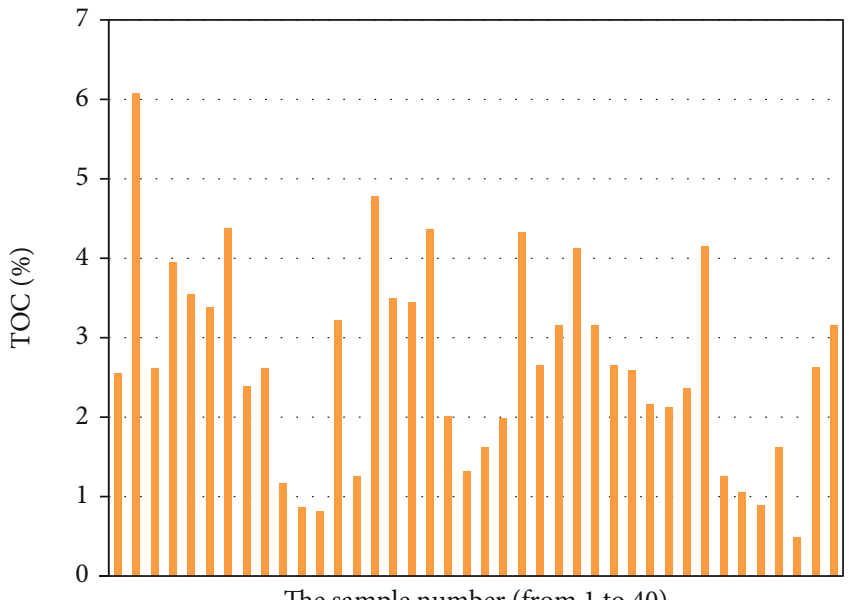

The sample number (from 1 to 40 )

FIgURE 4: Histogram of the TOC distribution of the Longmaxi Formation. the reservoir temperature, the formation pressure, the water saturation, and the composition of the natural gas [43]. For well XN111, the methane gas adsorption capacities of 22 samples ranged from 0.84 to $4.69 \mathrm{~m}^{3} / \mathrm{t}$, with an average of $2.92 \mathrm{~m}^{3} / \mathrm{t}$. The amount of gas adsorption and the TOC are positively correlated. That is, the greater the TOC, the greater the amount of gas adsorption. Organic matter has a strong gas adsorption potential, which can explain this phenomenon. A large amount of shale gas is adsorbed onto the surfaces of the kerogen in the shale, and the high TOC content indicates the large volume and adsorption capacity of the shale gas. The field measurements of the gas content reveal that the gas content of the lower shale of the Longmaxi Formation in well XN111 is greater than $3.0 \mathrm{~m}^{3} / \mathrm{t}$, and the overall adsorption capacity and gas content of the lower shale of the Longmaxi Formation are relatively large. For example, the isothermal adsorption data for the upper and lower shale reservoirs (samples 48409-4B and 48409-3B, respectively) in the Longmaxi Formation were compared. The methane 


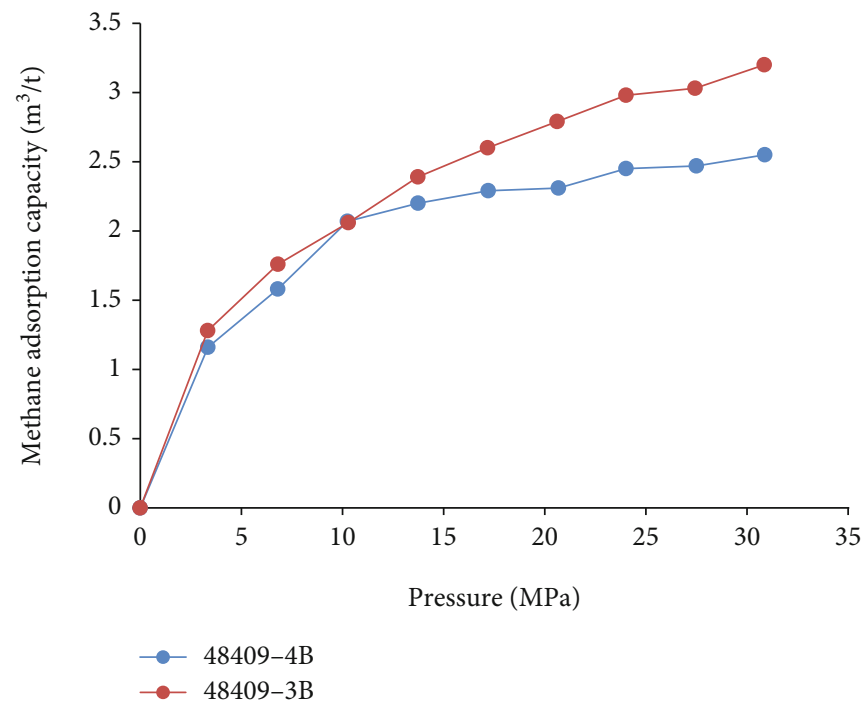

FIGURE 5: Isothermal adsorption curve for the Longmaxi Formation in well XN111.

adsorption capacity of upper sample $48409-4 \mathrm{~B}$ was $2.55 \mathrm{~m}^{3} / \mathrm{t}$, while that of lower sample $48409-3 \mathrm{~B}$ was $3.2 \mathrm{~m}^{3} / \mathrm{t}$. The methane adsorption capacity of the lower shale reservoir was $25.5 \%$ higher than that of the upper shale reservoir (Figure 5).

4.4. Reservoir Storage Space. The morphology, quantity, and distribution of the shale micropores were qualitatively observed using focused ion beam scanning electron microscope (FIB-SEM). According to the relationship between the pore development and rock particles, they can be divided into matrix pores (organic pores, clay mineral interlayer pores, berry pyrite intercrystalline pores, grain mineral edge pores, and secondary dissolution pores) and microfractures (Figure 6). The interbedded pores in the organic matter and clay minerals are the most well developed and are important components of the reservoir space.

The organic matter pores are secondary pores formed inside kerogen during diagenetic evolution from solid kerogen to hydrocarbon fluid $[44,45]$. They are mostly round, elliptical, and irregular polygons, and they are generally 10$150 \mathrm{~nm}$ in size. The dispersed organic matter is commonly associated with berry pyrite and clay minerals, and organic matter nanopores are developed in the pyrite grains and clay minerals. In the early deep-water continental shelf sedimentary environment of the Longmaxi Formation, a large amount of red algae was produced [46], and a large number of organic pores easily developed.

During the diagenetic evolution, the montmorillonite transformed into illite through the Aemon mixed layer. Intrapores were generated between the filamentous or curly illite, which were arranged in parallel with each other and had good connectivity. A berry pyrite micropellet formed in an anoxic environment, consisting of many small pyrite grains. The intercrystalline interP pores are nanopores. Calcite, feldspar, and other soluble minerals easily produce secondary dissolution pores through acid etching, which have a more irregular shape, are relatively isolated, and have poor connectivity. Micropores are easily developed on the edge of quartz and other rigid granular minerals. Their morphology is controlled by the original porosity and diagenesis [47, 48], and they are mostly triangular or irregular, with poor connectivity. The microfractures are more well developed, and most of them are serrated or curvilinear. Their extension length is large, and their widths are generally $50-100 \mathrm{~nm}$. They can provide storage space for free gas and can be helpful when analyzing the adsorbed gas. They are an important channel for gas seepage.

4.5. Reservoir Properties. The porosity of the Longmaxi shale is $0.86 \%$ to $8.44 \%$ (average $4.78 \%$ ). The permeability is very low, ranging from $0.0026 \mathrm{D}$ to $0.0328 \mathrm{D}$, with a mean of $0.0116 \mathrm{D}$. The analysis shows that the specific surface area ranges from $3.263 \mathrm{~m}^{2} / \mathrm{g}$ to $38.767 \mathrm{~m}^{2} / \mathrm{g}$, with average of $18.76 \mathrm{~m}^{2} / \mathrm{g}$. The specific surface area provided by the micropores is $2.712-21.69 \mathrm{~m}^{2} / \mathrm{g}$, with an average of $8.57 \mathrm{~m}^{2} / \mathrm{g}$, accounting for $45.68 \%$ of the specific surface area. The mean throat radius is $4 \mathrm{~nm}$ to $16.1 \mathrm{~nm}$, with a mean of $7.2 \mathrm{~nm}$. The total pore volume of the Longmaxi shale is $11 \times 10^{-4} \mathrm{ml} / \mathrm{g}$ to $321 \times 10^{-4} \mathrm{ml} / \mathrm{g}$, with an average of $109 \times 10^{-4} \mathrm{ml} / \mathrm{g}$. The pore volume provided by the micropores $(<2 \mathrm{~nm})$ is $2.5 \times 10^{-4}$ $\mathrm{ml} / \mathrm{g}$ to $22.3 \times 10^{-4} \mathrm{ml} / \mathrm{g}$, with an average of $10.3 \times 10^{-4} \mathrm{ml} /$ $\mathrm{g}$, accounting for an average of $9.45 \%$ of the total pore volume. The mesopore volume $(2 \mathrm{~nm}$ to $50 \mathrm{~nm})$ ranges from $31.4 \times 10^{-4} \mathrm{ml} / \mathrm{g}$ to $278 \times 10^{-4} \mathrm{ml} / \mathrm{g}$, with an average of $86 \times$ $10^{-4} \mathrm{ml} / \mathrm{g}$. The macropores $(>50 \mathrm{~nm}$ ) account for $11.65 \%$ of the total pore volume, indicating that the mesopores are dominant in the Longmaxi shale.

\section{Discussion}

\subsection{Main Factors Affecting Shale Gas Enrichment}

5.1.1. Stable Anoxic Deep-Water Sedimentary Environment. The stable anoxic deep-water sedimentary environment resulted in the widely distributed shale reservoir in wellblock XN111. 


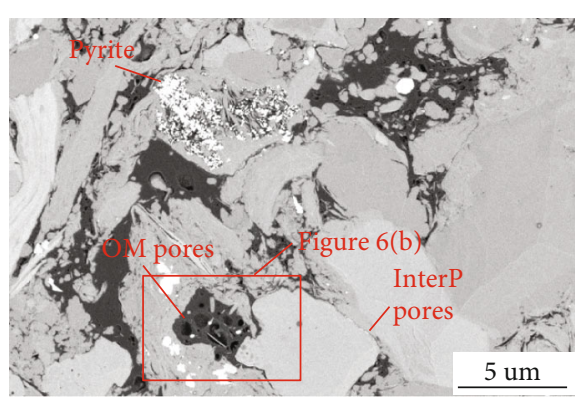

(a)

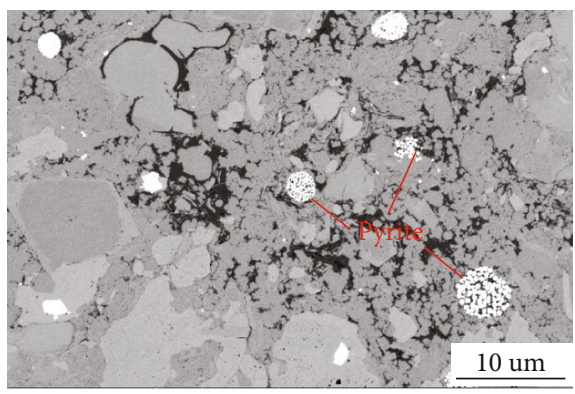

(c)

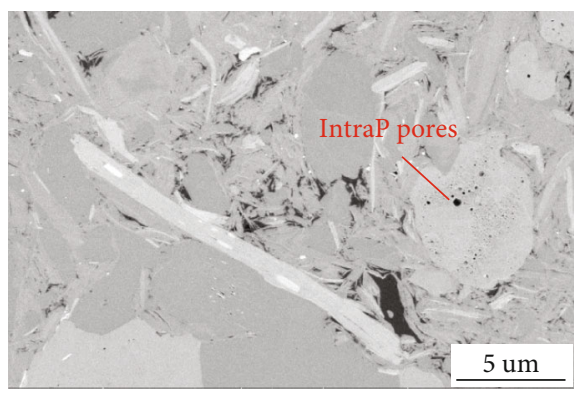

(e)

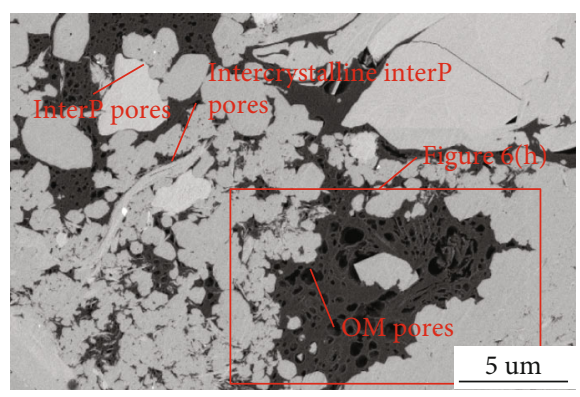

(g)

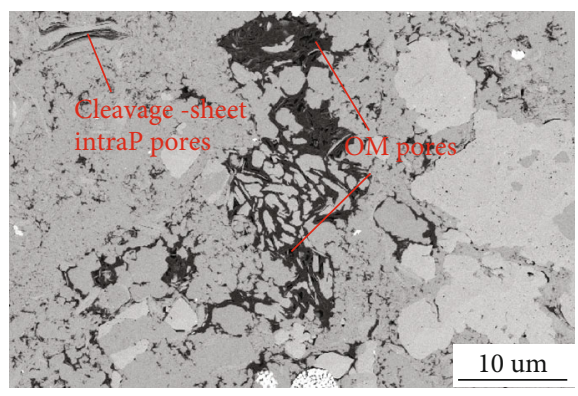

(i)

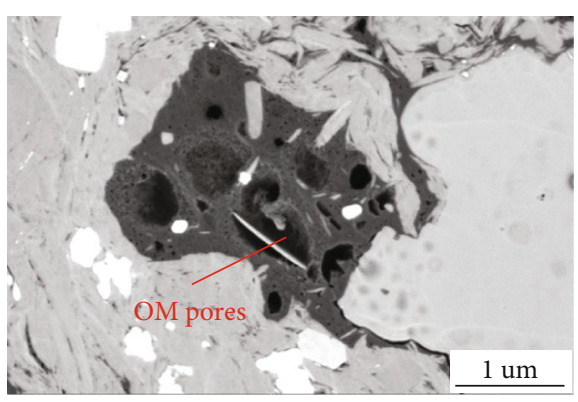

(b)

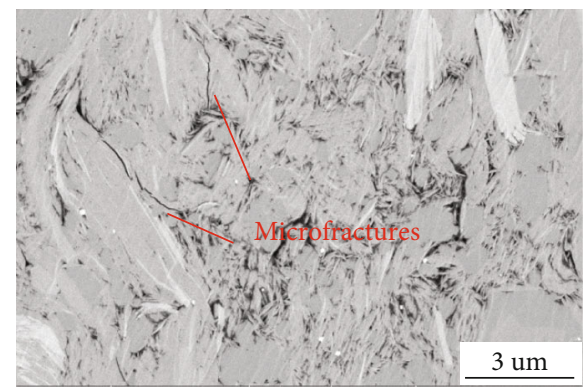

(d)

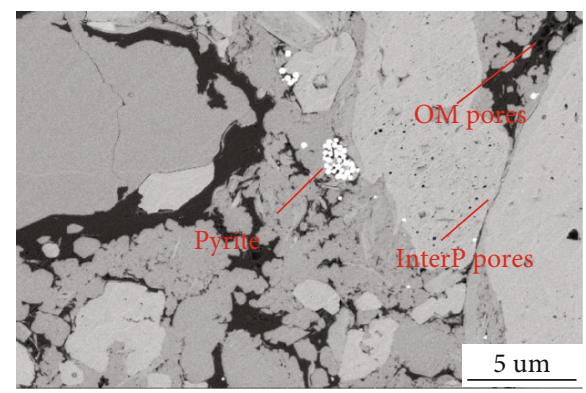

(f)

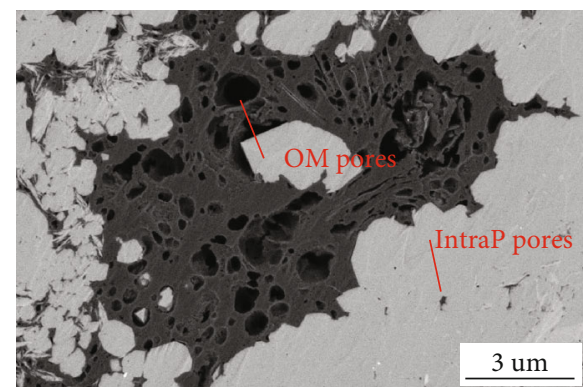

(h)

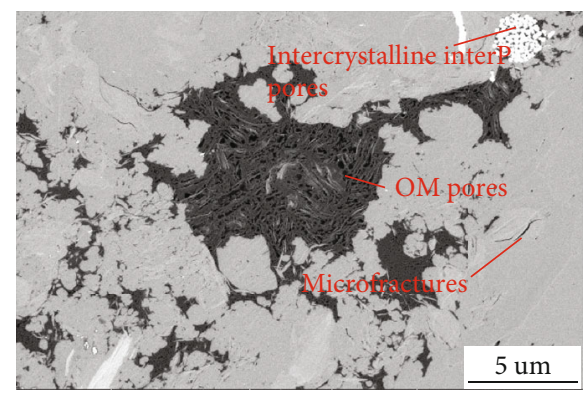

(j)

Figure 6: Continued. 


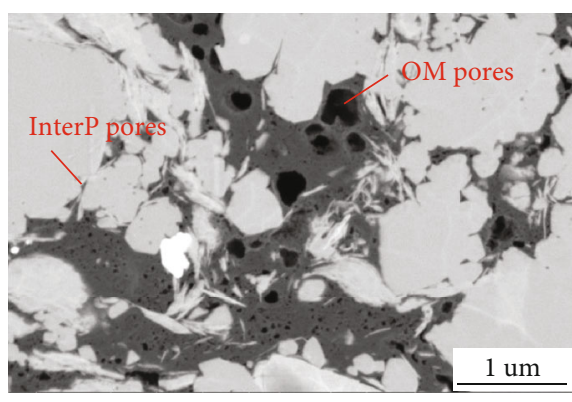

(k)

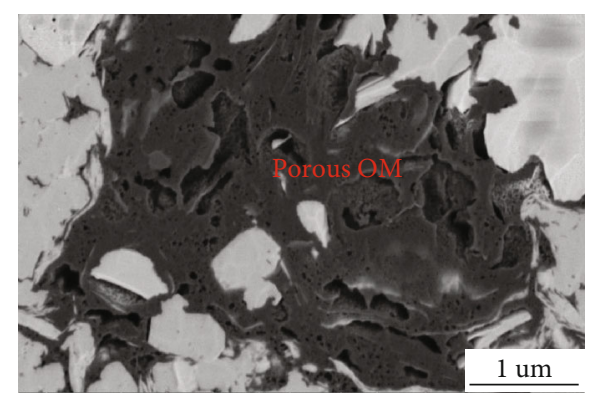

(1)

FIGURE 6: FE-SEM images of the shale samples from wellblock XN111. (a) OM pores, pyrite, and interP pores at the edges of mineral grains; (b) large OM particle with irregular and elliptical OM pores; (c) intercrystalline interP pores in pyrite framboids; (d) microfractures; (e) intraP pores with calcite grains; (f) OM pores and interP pores at the edge of a calcite grains; (g) interP pores at the edges of mineral grains, OM pores, and intercrystalline interP pores in clay particles; (h) fluid inclusion intraP pores within brittle minerals and OM pores in OM grains; (i) cleavage-sheet intraP pores within clay particles and OM pores; (j) intercrystalline interP pores in pyrite framboids, microfractures and OM particle with irregular and elliptical OM pores; (k) OM pores and interP pores at the edges of mineral grains; (l) porous OM particles.

A quiet and stable deep-water reducing environment is the best environment for the formation, development, and preservation of organic rich marine sediments. The early stage of the deposition of the Longmaxi Formation in well XN111 inherited the sedimentary characteristics of the Wufeng Formation. The main body of the sediment included deep-water continental shelf and semiconfined shallow sea facies [49]. In this period, the deposition rate was low, and the deposition time was more than half that of the Longmaxi period [50]. The deposition thickness was about 100-135 m, accounting for only $30-45 \%$ of the thickness of the entire Longmaxi Formation. Black carbonaceous siliceous shale and black shale were developed. In this period, the semiconfined deep-water shelf was relatively deep, quiet, and stable [51]. The sedimentary thickness was large and the organic matter was rich (graptolite development). The organic matter type was primarily I type, which indicates a high degree of thermal evolution. This was the main period for the development of effective source rocks in the Longmaxi Formation.

In the late period of the Longmaxi Formation, dark gray shale, gray mudstone, and silty mudstone assemblages were mainly deposited. The main body was deposited in a shallow water shelf environment. The deposition rate was significantly higher than that in the early period, and the deposition thickness was about 150-165 m (Figure 7). During this period, the water body was relatively shallow, the organic matter was relatively undeveloped, and the graptolite content decreased significantly.

Shale thickness is a prerequisite for commercial shale gas accumulation. Successful experiences in the United States have shown that the minimum thickness of black shale required for exploration and development of shale gas is $30 \mathrm{~m}$. The effective thickness of the Longmaxi Formation in well XN111 is relatively large. The thickness of the lower shale of the Longmaxi Formation increases from northwest to southeast with a thickness of about $120 \mathrm{~m}$. Over $50 \mathrm{~m}$ of fine black shale is present.

5.1.2. High TOC Content, Appropriate Organic Matter Type, and Thermal Maturity. Organic pores are the main storage space for shale gas. The TOC is an important factor in reservoir properties and shale gas accumulation. The formation of organic pores is related to the content of transformed organic carbon, which is controlled by the type of organic matter. The organic matter in the Longmaxi shale is mainly Type I kerogen, which is conducive to shale gas accumulation. Studies have shown that the TOC content is positively correlated with the shale gas adsorption and pore volume [52]. Shale gas accumulation requires a TOC of at least $0.5 \%$. The TOC content of the Longmaxi shale in the study area is high, with an average value of $2.66 \%$, which is far higher than the lower TOC limit, indicating that the shale gas reserves have a great potential.

Appropriate thermal maturity is very important for shale gas [53]. The vitrinite reflectance can reflect the thermal maturity and affect the shale gas concentration and the reservoir's physical properties. The average vitrinite reflectance of the Longmaxi shale is $2.05 \%$, which is suitable for the production and accumulation of natural gas. During the thermal evolution of organic matter, a series of physical and chemical reactions occur, including the transformation of organic carbon, the decomposition of organic matter, and the generation of hydrocarbons. Moreover, a large number of nanopores are generated in the source rocks, which can provide storage space for shale gas.

5.1.3. An Assemblage of Rocks and Minerals Prone to Fracturing. The rock mechanics data show that the Young's modulus of wellblock XN111 is 29,000 to $36,000 \mathrm{MPa}$, the Poisson's ratio is 0.16 to 0.18 , and the brittleness index can reach more than $65 \%$. This is due to the low content of clay minerals and the high content of brittle minerals (mainly siliceous minerals and carbonate minerals) in wellblock XN111, which makes the Longmaxi Formation shale easy to fracture and produce.

5.1.4. Widely Distributed Natural Fractures. Fractures provide important reservoirs for shale gas and can act as seepage channels for methane molecules. The image logging and core data show that the fracture width of the Longmaxi Formation 


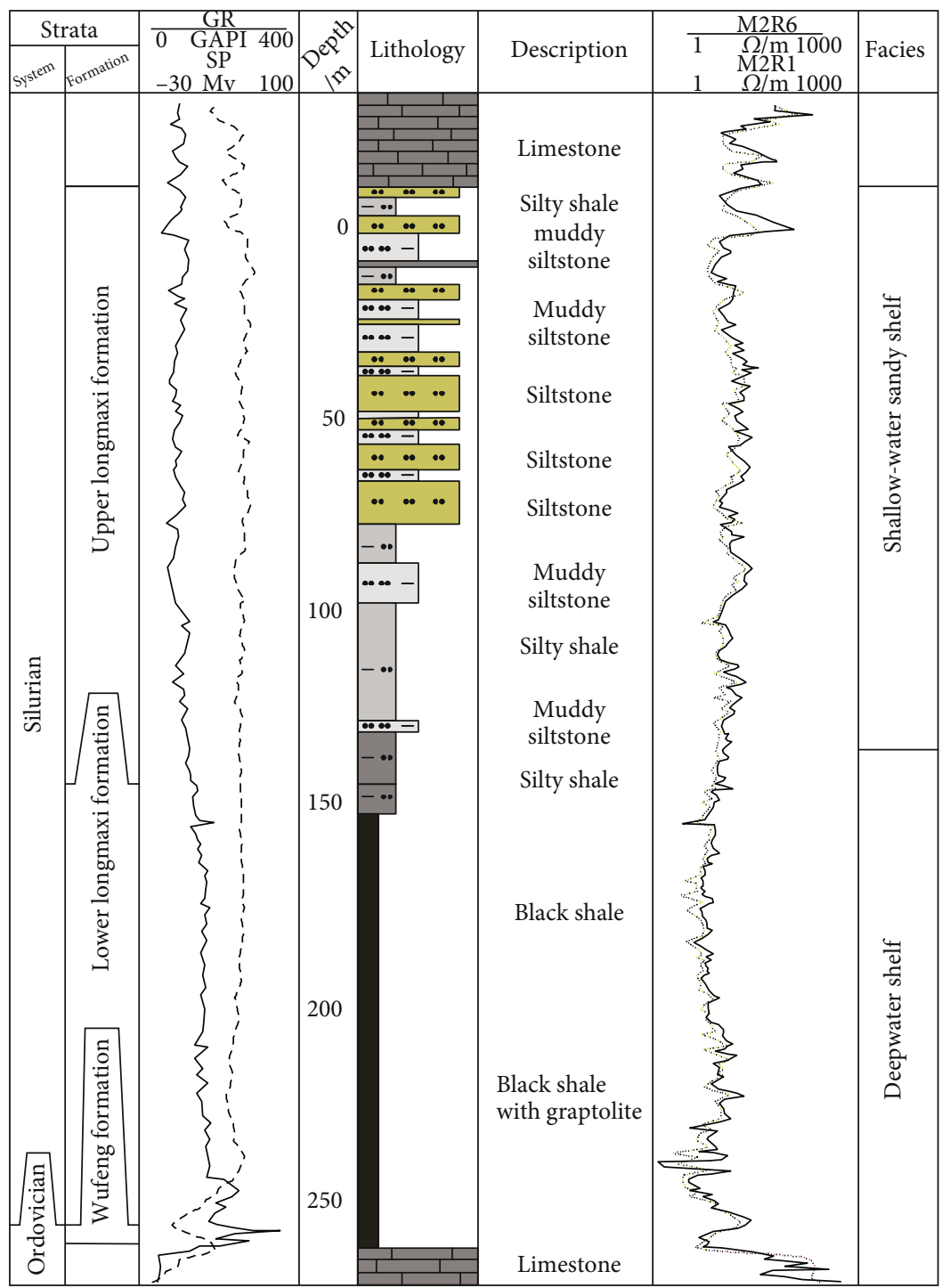

FIGURE 7: Sedimentary characteristics of the shale reservoir in the Longmaxi Formation, well XN111, Sichuan Basin.

is 0.5 to $1 \mathrm{~mm}$, and the fracture density of most of the wells is $0.4 / \mathrm{m}$ to $4 / \mathrm{m}$. These widely developed macroscopic fractures are important factors controlling the shale gas enrichment in the Longmaxi Formation. Due to the extremely low permeability of the shale system, a certain scale of structural fractures is conducive to improving the permeability of the shale reservoir and forming a dominant seepage channel, which is the key factor for high yield shale gas wells. The image logging data show that 87 high-resistance fractures are developed in the lower Longmaxi Formation in well $\mathrm{XN111}$, with an azimuth of $340-350^{\circ} \mathrm{NE}$, a strike of $70-80^{\circ}$ $\mathrm{NNE}$, and an inclination of $20-80^{\circ}$ (Figure 8). Similarly, shale fractures and diagenetic shrinkage fractures are also beneficial to improving the conductivity of shale reservoirs.

Microfractures form a bridge connecting the macroscopic fractures and microscopic pores. They play an important role in shale gas seepage. The microfractures in the Longmaxi Formation are well developed because the organic particles, brittle minerals, and clay minerals can develop microfractures. These large-scale microfractures are con- nected with other pores, forming a fracture network-pore system, which provides effective storage and seepage space for the natural gas trapped in the shale.

5.2. The Development Potential of the Longmaxi Shale Gas. The area of shale gas in well XN111 is about $390 \mathrm{~km}^{2}$. Thus far, several horizontal fracturing wells have been drilled, and good results have been achieved. The total shale thickness of the Longmaxi Formation in well XN111 is $30-210 \mathrm{~m}$. Among them, the lower part of the Longmaxi Formation has an effective shale thickness of $33.9 \mathrm{~m}$. The total porosity is 3$6 \%$, fractures are developed, and it is a high-quality source rock and reservoir (high TOC content, relatively high Ro content). The gas content is $3.82 \mathrm{~m}^{3} / \mathrm{t}$, and the pressure coefficient is 1.80. According to the volume method, the Longmaxi shale gas resources in wellblock XN111 can reach $1393.7 \times 10^{8} \mathrm{~m}^{3}$, and the reserve abundance is $3.57 \times 10^{8} \mathrm{~m}^{3} / \mathrm{km}^{2}$.

The maximum principal stress direction in this area is $\mathrm{NW}\left(300-310^{\circ}\right)$, and the natural fracture direction is NNE $\left(30^{\circ}\right)$. Both the fracturing effect and the drilling safety should 


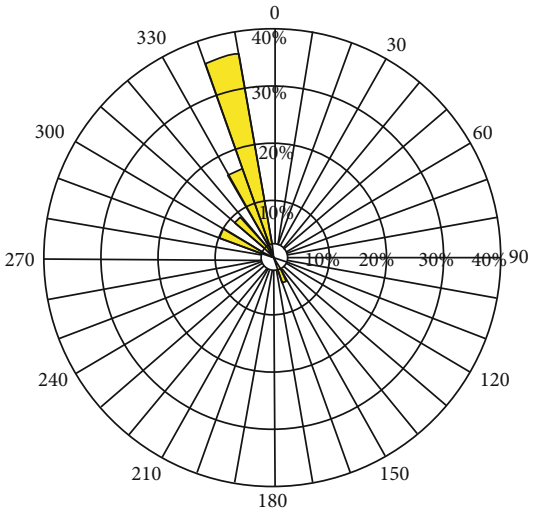

(a)

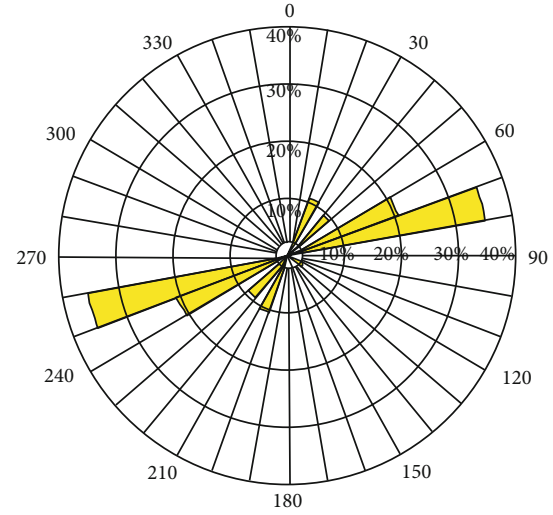

(b)

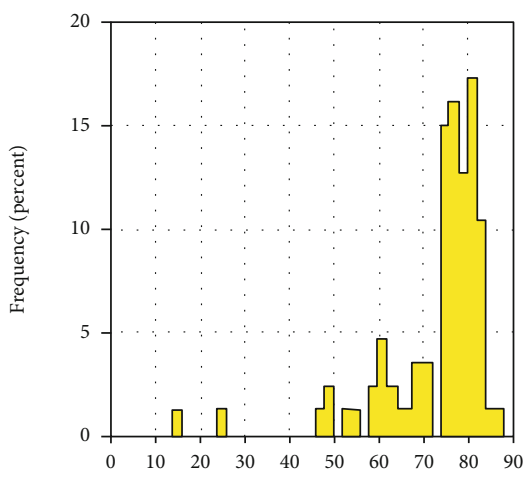

(c)

FIGURE 8: Fracture statistics of well XN111. (a) rosette (azimuth); (b) rosette (strike); (c) dip (degree).

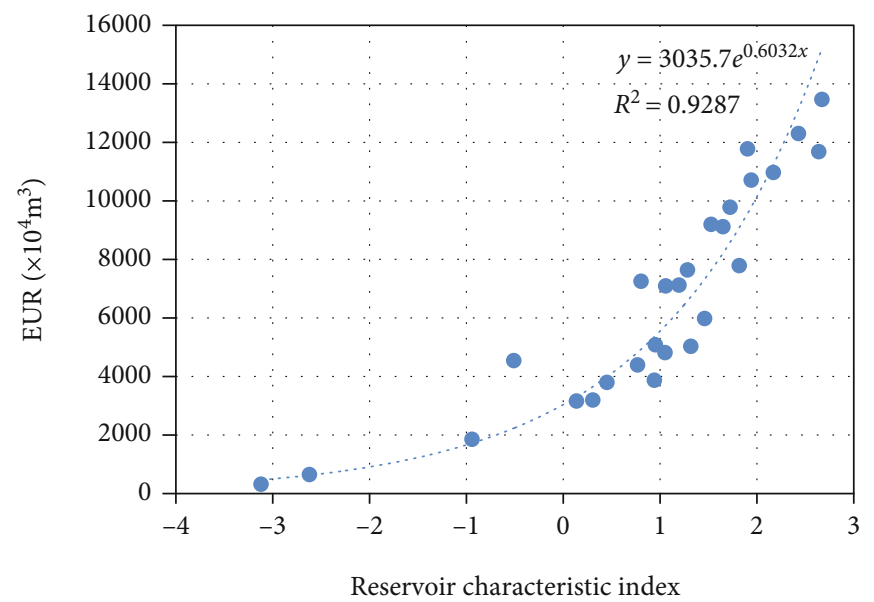

FIgURE 9: Plot of the reservoir characteristic index versus the EUR of wellblock XN111.

be considered when designing the horizontal well orientation. The horizontal trajectory orientation of the horizontal well group is selected at a certain angle with respect to the direction of the minimum principal stress and the natural fractures, comprehensively taking the natural fractures, structural morphology, and other factors into consideration. The best horizontal well trajectory directions for this area were determined to be $\mathrm{NE} 20^{\circ}$ and SW $200^{\circ}$. Since the highpressure dry gas shale reservoir in the Longmaxi Formation in the well XN111 area is mainly driven by elasticity, the exploitation of natural energy depletion was adopted in the early stage. When the wellhead pressure dropped to the pipeline pressure, pressurization was used for the mining. The production capacity was mainly maintained by means of interwell replacement.

Sensitivity analysis of the reservoir parameters affecting the shale production in the adjacent Longmaxi Formation was carried out. Five parameters, including the shale thickness, gas content, TOC, fracture density, and clay content, were selected. Among them, the high-quality shale thickness, 
gas content, TOC, and fracture density are positively correlated with gas well production, while clay content is negatively correlated with gas well production. The reservoir characteristic index was constructed, which is a comprehensive mathematical index that affects the production of shale gas wells. The mathematical relationship between the Estimated Ultimate Recovery (EUR) of a single well and the Reservoir Characteristic Index (Rci) (Figure 9) was established using the production data for the gas wells for which the production conditions are close to waste in the adjacent well area:

$$
\mathrm{EUR}=3035.7 e^{0.6032 \mathrm{Rci}}
$$

Based on the relationships between the single-well EUR, the initial production, and the comprehensive classification coefficient in the adjacent block, it was predicted that the single-well index in wellblock XN111 is $9666 \times 10^{4} \mathrm{~m}^{3}$. Factors controlling shale reservoirs were analyzed to clarify geochemical and mineralogical characteristics, which also provide the structure, reservoir space, and reservoir fluid parameters. The model of Estimated Ultimate Recovery (EUR) is comprehensive when considered all the most influential parameters: high-quality shale thickness, gas content, TOC, fracture density, and clay content. The model is efficient and convenient to use for various reservoir characteristics scenarios.

\section{Conclusions}

In this study, the characteristics and development potential of the shale reservoirs in the Lower Silurian Longmaxi Formation were analyzed by taking wellblock XN111 in the Sichuan Basin, southern China, as an example. Several important findings are summarized as follows.

(1) The widespread deep-water shelf deposition was a favorable environment for the development of high-quality shale hydrocarbon source rocks with a cumulative thickness of up to $50 \mathrm{~m}$. The high TOC content results in the shale reservoir having high free gas and adsorption gas storage capacity. The high maturity to over maturity of the shale is conducive to the formation of organic pores, and the pore space is dominated by mesopores $(2-50 \mathrm{~nm})$. The development of fractures further effectively improves the reservoir and the seepage capacity of the shale reservoirs

(2) The reservoir characteristic index was constructed using five parameters: high-quality shale thickness, gas content, TOC, fracture density, and clay content. The mathematical relationship between the Estimated Ultimate Recovery (EUR) of a single well and the Reservoir Characteristic Index (Rci) was established. It was predicted that the EUR of a single well in the well XN111 area is $9666 \times 10^{4} \mathrm{~m}^{3}$

\section{Data Availability}

The data used to support the findings of this study are available from the corresponding author upon request.

\section{Disclosure}

The findings achieved herein are solely the responsibility of the authors.

\section{Conflicts of Interest}

The authors declare that they have no conflicts of interest.

\section{Acknowledgments}

This study was financially supported by the PetroChina Innovation Foundation (2019D-5007-0210), National Natural Science Foundation of China (51904050 and 41902153), Open fund of Engineering Research Center of Development and Management for Low to Ultra-Low Permeability Oil \& Gas Reservoirs in West China, Ministry of Education (KFJJ-XB-2020-4), the Chongqing Natural Science Foundation Project (cstc2019jcyj-msxmX0725, 0457), Open fund of State Key Laboratory of Shale Oil and Gas Enrichment Mechanisms and Effective Development (G5800-20-ZSKFGY009), and the Science and Technology Research Program of Chongqing Municipal Education Commission (Grant no. KJQN201901531). We thank LetPub (http:// www.letpub.com) for its linguistic assistance during the preparation of this manuscript.

\section{References}

[1] C. R. Clarkson, B. Haghshenas, A. Ghanizadeh et al., "Nanopores to megafractures: current challenges and methods for shale gas reservoir and hydraulic fracture characterization," Journal of Natural Gas Science and Engineering, vol. 31, pp. 612-657, 2016.

[2] J. B. Curtis, "Fractured shale-gas systems," AAPG Bulletin, vol. 86, no. 11, pp. 1921-1938, 2002.

[3] R. Ariketi, K. U. Bhui, S. Chandra, and S. Biswal, "Brittleness modeling of Cambay shale formation for shale gas exploration: a study from Ankleshwar area, Cambay Basin, India," Journal of Petroleum Exploration Production Technology, vol. 17, no. 4, pp. 326-339, 2017.

[4] V. Rasouli, "Geomechanics of gas shales," in Fundamentals of Gas Shale Reservoirs, R. Rezaee, Ed., pp. 169-190, John Wiley \& Sons, Inc., Hoboken, NJ, USA, 2015.

[5] C. Luo, N. Yin, H. Lin, X. Gao, J. Wang, and H. Zhu, "Reservoir characteristics of the lower Silurian Longmaxi shale in Zhaotong region, southern China," Geofluids, vol. 2020, Article ID 8872244, 11 pages, 2020.

[6] R. G. Loucks, R. M. Reed, S. C. Ruppel, and D. M. Jarvie, "Morphology, genesis, and distribution of nanometer-scale pores in siliceous mudstones of the Mississippian Barnett shale," Journal of Sedimentary Research, vol. 79, no. 12, pp. 848-861, 2009.

[7] Y. Guo, L. Wang, X. Chang, J. Zhou, and J. Shu, "Study on fracture morphological characteristics of refracturing for Longmaxi shale Formation," Geofluids, vol. 2020, Article ID 1628431, 13 pages, 2020. 
[8] C. Jia, M. Zheng, and Y. Zhang, "Unconventional hydrocarbon resources in China and the prospect of exploration and development," Petroleum Exploration and Development, vol. 39, no. 2, pp. 139-146, 2012.

[9] P. Wang, C. Zou, X. Li et al., "Main geological controlling factors of shale gas enrichment and high yield in Zhaotong demonstration area," Acta Petrolei Sinica, vol. 39, no. 7, pp. 744$753,2018$.

[10] L. Zhang, B. Li, S. Jiang et al., "Heterogeneity characterization of the lower Silurian Longmaxi marine shale in the Pengshui area, South China," International Journal of Coal Geology, vol. 195, pp. 250-266, 2018.

[11] L. Chen, Z. Jiang, K. Liu, J. Tan, F. Gao, and P. Wang, "Pore structure characterization for organic-rich Lower Silurian shale in the Upper Yangtze Platform, South China: a possible mechanism for pore development," Journal of Natural Gas Science and Engineering, vol. 46, pp. 1-15, 2017.

[12] F. Shang, Y. Zhu, H. Gao, Y. Wang, and R. Liu, "Relationship between tectonism and composition and pore characteristics of shale reservoirs," Geofluids, vol. 2019, Article ID 9426586, 14 pages, 2019.

[13] X. Liang, Z. Xu, and Z. Zhang, "Breakthrough of shallow shale gas exploration in Taiyang anticline area and its significance for resource development in Zhaotong, Yunnan province, China," Petroleum Exploration and Development, vol. 47, no. 1, pp. 1-18, 2020.

[14] X. Wang, Z. Jiang, and S. Jiang, "Full-scale pore structure and fractal dimension of the Longmaxi shale from the Southern Sichuan Basin: investigations using FE-SEM, gas adsorption and mercury intrusion porosimetry," Minerals, vol. 543, no. 9, pp. 1-26, 2019.

[15] D. J. K. Ross and R. M. Bustin, "Investigating the use of sedimentary geochemical proxies for paleoenvironment interpretation of thermally mature organic-rich strata: examples from the Devonian-Mississippian shales, Western Canadian Sedimentary Basin," Chemical Geology, vol. 260, no. 1-2, pp. 1-19, 2009.

[16] L. Chorn, J. Yarus, S. D. Rosario-Davis, and J. Pitcher, "Identification of shale sweet spots using key property estimates from log analysis and geostatistics," in Unconventional Resources Technology Conference, pp. 1511-1523, Denver, CO, UDS, August 2013.

[17] I. Y. Akkutlu and E. Fathi, "Multiscale gas transport in shales with local kerogen heterogeneities," SPE Journal, vol. 17, no. 4, pp. 1002-1011, 2012.

[18] R. D. Vidic, S. L. Brantley, J. M. Vandenbossche, D. Yoxtheimer, and J. D. Abad, "Impact of shale gas development on regional water quality," Science, vol. 340, no. 6134, article 1235009, 2013.

[19] J. Yang, J. Leng, L. Qiao, L. Wang, and J. Ding, "Parameter prediction of water imbibition in unsaturated shales using the NMR method," Geofluids, vol. 2019, Article ID 4254159, 9 pages, 2019.

[20] K. H. Hashmy, S. Abuelta, and C. Barnett, "Log-based identification of sweet spots for effective fracs in shale reservoirs," in Canadian Unconventional Resources Conference, pp. 1-11, Calgary, Canada, November 2011.

[21] M. E. Curtis, B. J. Cardott, C. H. Sondergeld, and C. S. Rai, "Development of organic porosity in the Woodford shale with increasing thermal maturity," International Journal of Coal Geology, vol. 103, pp. 26-31, 2012.
[22] Y. Wan and S. H. Tang, "Evaluation of the shale gas potential of the lower Silurian Longmaxi Formation in northwest Hunan Province, China," Marine and Petroleum Geology, vol. 79, pp. 159-175, 2017.

[23] P. Sarkar, K. H. Singh, R. Ghosh, and T. N. Singh, "Estimation of elastic parameters, mineralogy and pore characteristics of Gondwana shale in Eastern India for evaluation of shale gas potential," Current Science, vol. 115, no. 4, pp. 710 720, 2018.

[24] Y. Wang, Y. Qin, R. Zhang et al., "Evaluation of nanoscale accessible pore structures for improved prediction of gas production potential in Chinese marine shales," Energy and Fuels, vol. 32, no. 12, pp. 12447-12461, 2018.

[25] K. Chen, J. Zhang, X. Tang, J. Yu, Y. Liu, and C. Yang, "Main controlling factors on shale adsorption capacity of the Lower Silurian Longmaxi Formation in western Hunan-Hubei area," Oil and Gas Geology, vol. 37, no. 1, pp. 23-29, 2016.

[26] Y. Ma, Z. Pan, N. Zhong et al., "Experimental study of anisotropic gas permeability and its relationship with fracture structure of Longmaxi Shales, Sichuan Basin, China," Fuel, vol. 180, pp. 106-115, 2016.

[27] J. Tan, B. Horsfield, R. Fink et al., "Shale gas potential of the major marine shale formations in the Upper Yangtze Platform, South China, part III: mineralogical, lithofacial, petrophysical, and rock mechanical properties," Energy and Fuels, vol. 28, no. 4, pp. 2322-2342, 2014.

[28] N. Sheikh and P. H. Giao, "Evaluation of shale gas potential in the Lower Cretaceous Sembar Formation, the Southern Indus Basin, Pakistan," Journal of Natural Gas Science and Engineering, vol. 44, pp. 162-176, 2017.

[29] Q. Guo, X. Chen, X. Liuzhuang et al., "Evaluation method for resource potential of shale oil in the Triassic Yanchang Formation of the Ordos Basin, China," Energy Exploration and Exploitation, vol. 38, no. 4, pp. 841-866, 2020.

[30] N. L. Viet and S. Hyundon, "Development of reservoir economic indicator for Barnett Shale gas potential evaluation based on the reservoir and hydraulic fracturing parameters," Journal of Natural Gas Science and Engineering, vol. 66, pp. 159-167, 2019.

[31] L. Chen, Z. Jiang, K. Liu et al., "Effect of lithofacies on gas storage capacity of marine and continental shales in the Sichuan Basin, China," Journal of Natural Gas Science and Engineering, vol. 36, pp. 773-785, 2016.

[32] Y. F. Li, D. Y. Shao, H. G. Lv, Y. Zhang, X. L. Zhang, and T. W. Zhang, "A relationship between elemental geochemical characteristics and organic matter enrichment in the marine shale of Wufeng Formation-Longmaxi Formation Sichuan Basin," Acta Petrolei Sinica, vol. 36, pp. 1470-1483, 2015.

[33] M. Qin, Z. Cao, and J. Guo, "Characteristics of shale reservoir and sweet spot identification of the Lower Cambrian Niutitang Formation in Northwestern Hunan Province, China," Acta Geologica Sinica, vol. 93, no. 3, pp. 573-587, 2019.

[34] S. Zhang, H. Liu, and Y. Liu, "Main controls and geological sweet spot types in Paleogene shale oil rich areas of the Jiyang Depression, Bohai Bay basin, China," Marine and Petroleum Geology, vol. 111, pp. 576-587, 2020.

[35] C. Zou, "Shale gas in China: characteristics, challenges and prospects," Petroleum Exploration \& Development, vol. 42, no. 6, pp. 689-701, 2015.

[36] W. B. Su, Z. M. Li, F. R. Ettensohn et al., "Distribution of black shale in the Wufeng-Longmaxi Formations (Ordovician- 
Silurian), South China: major controlling factors and implications," Earth Science, vol. 32, no. 6, pp. 819-827, 2007.

[37] C. Chen, D. Hu, D. Westacott, and D. Loveless, "Nanometerscale characterization of microscopic pores in shale kerogen by image analysis and pore-scale modeling," Geochemistry, Geophysics, Geosystems, vol. 14, no. 10, pp. 4066-4075, 2013.

[38] H. Zhu, A. Jia, and Y. Wei, "Characteristics of microscopic pore structure and methane adsorption capacity of shale in the Longmaxi Formation in the Zhaotong area," Petroleum Geology and Recovery Efficiency, vol. 25, no. 4, pp. 1-6, 2018.

[39] G. Wang, A. Jia, Y. Wei, and C. Xiao, "Transient pressure analysis for multifractured horizontal well with the use of multilinear flow model in shale gas reservoir," Geofluids, vol. 2019, Article ID 8348205, 20 pages, 2019.

[40] B. Ran, S. G. Liu, L. Jansa et al., "Reservoir characteristics and preservation conditions of Longmaxi shale in the upper Yangtze block, South China," Acta Geologica Sinica, vol. 90, no. 6, pp. 2182-2205, 2016.

[41] X. Tang, Z. Jiang, S. Jiang, and Z. Li, "Heterogeneous nanoporosity of the Silurian Longmaxi Formation shale gas reservoir in the Sichuan Basin using the QEMSCAN, FIB-SEM, and nanoCT methods," Marine and Petroleum Geology, vol. 78, pp. 99109, 2016.

[42] Y. Shu, Y. Lu, and L. Chen, "Factors influencing shale gas accumulation in the lower Silurian Longmaxi formation between the north and south Jiaoshiba area, Southeast Sichuan Basin, China," Marine and Petroleum Geology, vol. 111, pp. 905917, 2020.

[43] E. Fathi and I. Y. Akkutlu, "Matrix heterogeneity effects on gas transport and adsorption in coalbed and shale gas reservoirs," Transport in Porous Media, vol. 80, no. 2, pp. 281-304, 2009.

[44] C. Lyu, Z. Ning, Q. Wang, and M. Chen, "Application of NMRT2to pore size distribution and movable fluid distribution in tight sandstones," Energy \& Fuels, vol. 32, no. 2, pp. 1395-1405, 2018.

[45] R. Holmes, H. Aljamaan, V. Vishal, J. Wilcox, and A. R. Kovscek, "Idealized shale sorption isotherm measurements to determine pore capacity, pore size distribution, and surface area," Energy \& Fuels, vol. 33, no. 2, pp. 665-676, 2019.

[46] F. X. Huang, H. D. Chen, M. C. Hou, Y. J. Zhong, and J. Li, "Filling process and evolutionary model of sedimentary sequence of Middle-Upper Yangtze craton in Caledonian (Cambrian-Silurian)," Acta Geologica Sinica, vol. 27, no. 8, pp. 2299-2317, 2011.

[47] J. Li, K. Wu, Z. Chen et al., "Effects of energetic heterogeneity on gas adsorption and gas storage in geologic shale systems," Applied Energy, vol. 251, article 113368, 2019.

[48] F. Yang, Z. Ning, R. Zhang, H. Zhao, and B. M. Krooss, "Investigations on the methane sorption capacity of marine shales from Sichuan Basin, China," International Journal of Coal Geology, vol. 146, pp. 104-117, 2015.

[49] X. Liang, G. Wang, and Z. Xu, "Comprehensive evaluation technology for shale gas sweet spots in the complex marine mountains, South China: a case study from Zhaotong national shale gas demonstration zone," Natural Gas Industry, vol. 36, no. 1, pp. 33-42, 2016.

[50] Z. X. Jiang, L. Guo, and C. Liang, "Lithofacies and sedimentary characteristics of the Silurian Longmaxi Shale in southeastern Sichuan Basin, China," Journal of Palaeogeography, vol. 2, no. 3, pp. 238-251, 2013.
[51] H. R. Zheng, B. Gao, Y. M. Peng, H. K. Nie, and F. R. Yang, "Sedimentary evolution and shale gas exploration direction of the lower Silurian in Middle-Upper Yangze area," Journal of Palaeogeography, vol. 15, no. 5, pp. 645-656, 2013.

[52] R. G. Loucks, R. M. Reed, S. C. Ruppel, and U. Hammes, "Spectrum of pore types and networks in mudrocks and a descriptive classification for matrix-related mudrock pores," AAPG Bulletin, vol. 96, no. 6, pp. 1071-1098, 2012.

[53] G. R. Chalmers, R. M. Bustin, and I. M. Power, "Characterization of gas shale pore systems by porosimetry, pycnometry, surface area, and field emission scanning electron microscopy/ transmission electron microscopy image analyses: examples from the Barnett, Woodford, Haynesville, Marcellus, and Doig units," AAPG Bulletin, vol. 96, no. 6, pp. 1099-1119, 2012. 